\title{
Increasing Rice Yield Through Amelioration and Fertilization on Medium Freshwater Swampland
}

\author{
Anna Hairani ${ }^{1}$, Muhammad Alwi ${ }^{1}$, and Khairil Anwar ${ }^{1}$ \\ ${ }^{1}$ Indonesian Swampland Agricultural Research Institute, Jalan Kebun Karet, Loktabat Utara, Banjarbaru, 70712, South \\ Kalimantan, Indonesia
}

\begin{abstract}
A big potential of freshwater swampland to overcome the land depreciation and the effects of drought in some land typologies during climate anomalies such as El Nino. Some of the freshwater swampland has been utilized by farmers for food crops, horticulture, fisheries, and livestock, but its utilization and productivity are still low and needs to be improved. The research was conducted on 2.5 ha of medium freshwater swampland at Hamayung village, Daha Utara district, Hulu Sungai Selatan Regency, South Kalimantan in dry season 2017. The experiment used a randomized block design with six treatments and three replicates. The treatments were: (1) Application of Pistia stratiotes + Biotara + Decision Support System (DSS) fertilization system; (2) Application of Pistia stratiotes + Biotara + recommended fertilization system; (3) Application without Pistia stratiotes + Biotara + DSS fertilization system; (4) Application without Pistia stratiotes + Biotara + recommended fertilization system; (5) Only Pistia stratiotes; and (6) Control. Soil tillage was carried out with minimum tillage. The rice variety was Inpara (Inbrida padi rawa) 2, which is high yield varieties for a swampy area that $\mathrm{Fe}$ tolerant with a planting system of jajar legowo (jarwo) $2: 1(25 \mathrm{~cm}-50 \mathrm{~cm}) \times 12.5 \mathrm{~cm}$. The results showed that a combination treatment of $15 \mathrm{t} / \mathrm{ha}$ in situ weed of Pistia stratiotes/ha +25 $\mathrm{kg}$ Biotara/ha + DSS fertilization system (50 kg urea/ha $+37 \mathrm{~kg} \mathrm{SP} 36 / \mathrm{ha}+24 \mathrm{~kg} \mathrm{KCl} / \mathrm{ha})$ gave the highest yield $(7.62 \mathrm{t} / \mathrm{ha})$. This treatment increased yield by $10.28 \%$ compared to control (6.91 t/ha) and was higher (52.40-69.33\%) than those yielded by local farmers cultivation (4.5$5.0 \mathrm{t} / \mathrm{ha})$
\end{abstract}

\section{Introduction}

Freshwater swampland is one of the agro-ecosystems in Indonesia. Every year it will be flooded with a minimum depth of $50 \mathrm{~cm}$ for at least three months. Based on the depth and duration of the inundation, freshwater swampland is classified into shallow, medium, and deep freshwater swampland. Medium freshwater swampland is flooded by water $50-100 \mathrm{~cm}$ depth during 3-6 months [1].

It is estimated that total area of freshwater swampland in Indonesia is 13.28 million ha, which spread over the islands of Sumatera, Kalimantan, Sulawesi, and Papua consisting of 4.17 million ha shallow freshwater swampland, 6.08 million ha medium freshwater swampland, and 3.04 million ha deep freshwater swampland [2]. About 1.55 million ha of freshwater swampland has been reclaimed for paddy field and settlement. This indicates that Indonesia still has a huge area of freshwater swampland (11.73 million ha) which can be developed as prospective agricultural production areas. In South Kalimantan, the area of freshwater swampland is 1.167 million ha, which is suitable for the development of food crops around 0.95 million ha [3]. The largest area is in Tapin, Hulu Sungai Utara, and Hulu Sungai Selatan regency.

A big potential of freshwater swampland to overcome the land depreciation and the effects of drought in some land typologies during climate anomalies such as El Nino. Some of the freshwater swampland has been utilized by farmers for food crops, horticulture, fisheries, and livestock, but its utilization and productivity are still low and needs to be improved. The low yield is not only being closely related to the physicochemical constraints of the land but also caused by the selection and application of technology that still does not match local site-specific and socio-cultural conditions. By applying appropriate technology, land quality can gradually be improved so that the carrying capacity of it becomes greater [4].

Amelioration is an effort to improve soil quality by providing ameliorant in the form of organic and inorganic materials to support plant growth and production. In the freshwater swampland area, farmers usually use straw or crop residues and weed in situ, such as Pistia stratiotes, Salvinia molesta, and Eichhornia crassipes as ameliorant and mulch material. However, there is a diversity of application techniques at the farmer level in their use, and since it is applied naturally, it causes nutrient competition with rice. Those three weeds were potential organic fertilizer due to its contained important elements for plants [5].

Fertilization is intended to provide sufficient nutrients to support plant growth. Improper dosage of fertilizer can cause low productivity of freshwater swampland. Farmers generally provide fertilizer based on their ability so that they often do not meet crop needs. There is a loss of $40-70 \% \mathrm{~N}, 80-90 \% \mathrm{P}$, and $50-70 \% \mathrm{~K}$ of fertilizer applied to the soil due to leaching, evaporation, immobilization, or fixation by soil components [6]. Therefore, to increase the effectiveness of fertilization, the application of fertilization was provided based on the results of the DSS analysis. DSS fertilization system is a Balitbangtan innovation software

\footnotetext{
Corresponding author: annagp8@gmail.com
} 
to determine the fertilizer requirements for rice in swampland based on soil nutrient status. This fertilization concept refers to the balance of nutrients required by plants based on the ability of the soil to provide nutrients [7]. This application is very simple and easily understood by users and can be accessed at http://www.balittra.litbang.pertanian.go.id.

\section{Material and Method}

The study was conducted in 2017 on 2.5 ha of medium freshwater swampland, Hamayung Village, Daha Utara District, Hulu Sungai Selatan Regency, South Kalimantan. The experiment used a randomized block design with six treatments and three replicate. The treatments were: (1) Application of Pistia stratiotes + Biotara + Decision Support System (DSS) fertilization system (K+B+DSS); (2) Application of Pistia stratiotes + Biotara + recommended fertilization system $(\mathrm{K}+\mathrm{B}+\mathrm{R})$; (3) Application without Pistia stratiotes + Biotara + DSS fertilization system (TK+B+DSS); (4) Application without Pistia stratiotes + Biotara + recommended fertilization system $(\mathrm{TK}+\mathrm{B}+\mathrm{R})$; (5) Only Pistia stratiotes (K); and (6) Control. Biotara was applied at 15 days before planting with a dose of $25 \mathrm{~kg} / \mathrm{ha}$. The recommended fertilizer dosage in freshwater swampland was $200 \mathrm{~kg}$ urea/ha+150 kg SP36/ha+100 kg KCl/ha whereas based on DSS analysis, the study site required $50 \mathrm{~kg}$ urea/ha+37 kg SP36/ha+24 kg KCl/ha. Soil tillage was carried out with minimum tillage. The rice variety was Inpara (Inbrida padi rawa) 2, which is high yield varieties for a swampy area that $\mathrm{Fe}$ tolerant. Jarwo planting system $2: 1(25 \mathrm{~cm}-50 \mathrm{~cm}) \times 12.5 \mathrm{~cm}$ was used to plant rice. Pest management was carried out with an integrated pest management system. Soil samples were collected at the beginning of planting for measuring $\mathrm{pH}$, $\mathrm{N}$, available $\mathrm{P}$, exchangeable $\mathrm{K}$ to determine the DSS fertilizer system. Plant height (TT) and many tillers (JA) were be observed at 30 and 60 days after planting (DAP) for rice growth performance. Meanwhile, rice yield was being recorded at the harvest time.

\section{Result and Discussion}

\subsection{Result}

Data on the dynamics of the water level $(50-100 \mathrm{~cm})$ and the length of inundation from November or December until June of the following year under normal rainfall showed that the study site was classified as medium freshwater swampland. Based on the soil taxonomy, the study site was Typic Endoaquept which has acidic to very acidic of $\mathrm{pH} \mathrm{H}_{2} \mathrm{O}(4.17-4.87)$, total $\mathrm{N}$ was classified as moderate $(0.22-0.48 \%)$, available $\mathrm{P}$ was very low to low (1.55-3.46 ppm $\mathrm{P}$ ) and exchangeable $\mathrm{K}$ criteria of low to moderate $\left(0.12-0.41 \mathrm{cmol}(+) \mathrm{kg}^{-1}\right)$. The following are the chemical characteristics of the composite soil analysis: electrical conductivity; $0.08 \mathrm{mS} \mathrm{cm}$, Corganic; $1.89 \%$, total $\mathrm{P} ; 5.03 \mathrm{mg} 100 \mathrm{~g}^{-1}$, total $\mathrm{K} ; 10.81$ mg $100 \mathrm{~g}^{-1}$, exchangeable $\mathrm{Ca} ; 7.5 \mathrm{cmol}(+) \mathrm{kg}^{-1}$, exchangeable $\mathrm{Mg} ; 3.92 \mathrm{cmol}(+) \mathrm{kg}^{-1}$, cation exchange capacity (CEC); $44.63 \mathrm{cmol}(+) \mathrm{kg}^{-1}$, exchangeable Al; $0.46 \mathrm{cmol}(+) \mathrm{kg}^{-1}$, exchangeable $\mathrm{H} ; 1.15 \mathrm{cmol}(+) \mathrm{kg}^{-1}, \mathrm{Fe}$; $532.95 \mathrm{ppm}$ and $\mathrm{SO}_{4} ; 490.65 \mathrm{ppm}$. Determination of nutritional status based on criteria from [8]. These results showed that fertilizer application especially N, P, and K fertilizer is needed in sufficient quantities to support the good performance of rice growth.

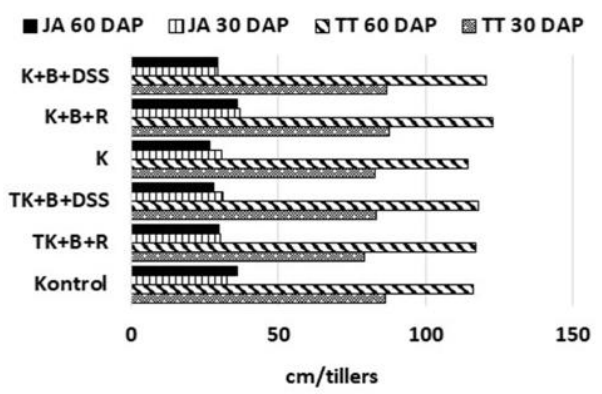

Figure 1. Plant height and number of tillers at 30 DAP and 60 DAP in each treatment

The results of observations of plant height and number of tillers at 30 and 60 DAP were presented in Figure 1. The treatment did not show differences in plant height and number of tillers either at 30 DAP or 60 DAP. Plant height at 30 DAP ranged from $79.40 \mathrm{~cm}$ to 87.80 $\mathrm{cm}$ and $114.27 \mathrm{~cm}$ to $122.73 \mathrm{~cm}$ at 60 DAP. For the number of tillers were $29.60-36.87$ at 30 DAP and 26.8736.20 tillers at 60 DAP observations.

Figure 2, showed that the application of the Pistia stratiotes + Biotara+DSS fertilization system ( $\mathrm{K}+\mathrm{B}+\mathrm{DSS})$ yielded $7.62 \mathrm{t} / \mathrm{ha}$. This yield increased by $10.28 \%$ compared to control (6.91 t/ha) and 52.40-69.33\% higher than the results obtained by local farmers $(4.5-5.0 \mathrm{t} / \mathrm{ha})$.

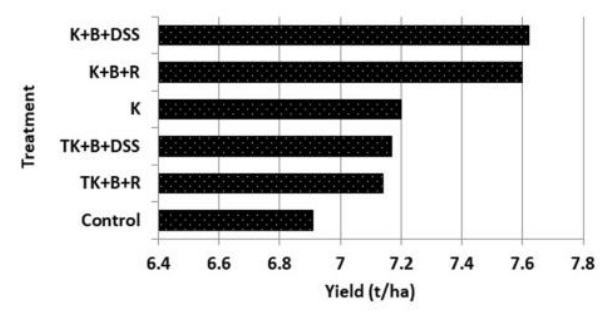

Figure 2. Yield $(\mathrm{t} / \mathrm{ha})$ on treatment.

\subsection{Discussion}

The improvement of land management technology is focused on increasing rice productivity by increasing planting index from 100 to 200. Planting index 200 can be achieved through water management by making mini polder, using high yield varieties, Jarwo planting systems, Biotara bio-fertilizers, fertilizing applications based on DSS, and integrated crop pest management.

Unpredictable water flooding fluctuation is the specific problems in freshwater swampland for agriculture. A polder system is one of the solutions. The principle of water management with this system is building mini polder equipped with water pumps and water pipes that function to remove and enter the water 
to maintain the groundwater level following plant requirements. Mini polder is built of embankment material dug near or parallel to the embankment line.

Using of high yield varieties and planting systems of Jajar legowo (Jarwo) is a technological innovation that is cheap and easily implemented by farmers [9]. High yield variety is one component of technology that plays a role in increasing production and yield quality. The results showed that high yield varieties could increase the production of freshwater swampland around 5-7 tons/ha. The description of Inpara 2 is 128 days old, 103 $\mathrm{cm}$ in height plant, productive tillers of 16 tillers, fluffier rice texture, amylose content $22.05 \%$, an average yield of $5.49 \mathrm{t} / \mathrm{ha}$ in freshwater swampland, and $4.82 \mathrm{t} / \mathrm{ha}$ in tidal swampland, a potential yield of $6.08 \mathrm{t} / \mathrm{ha}$, moderately resistant to the biotype 2 brown planthopper, resistant to pathotype III leaf blight, resistant to blasts, and tolerant of $\mathrm{Fe}$ and $\mathrm{Al}$ toxicity [10].

The Jarwo technology is a rice planting technique by adjusting the spacing between clumps and rows, resulting in compaction of rice clumps in rows and widening the distance between rows. The distance between the rows is expected to facilitate maintenance, such as weeding, fertilizing, and controlling pests and diseases. Rice yield on the Jarwo planting system is higher than the tile planting system due to increased production per clump caused by all ranks of rice plants.

Biotara containing decomposer microbes Trichoderma sp. was used to accelerate the decomposition of Pistia stratiotes. In addition to accelerating the decomposition of organic residues, this bio-fertilizer is also useful to boost plant growth, increase the efficiency of $\mathrm{N}$, and $\mathrm{P}$ fertilization as $30 \%$, as well as increase rice yield by more than $20 \%$ in swampland The nutrients contained in Pistia stratiotes is $35.20-44.47 \%$ of C-organic, $0.81-2.67 \%$ of $\mathrm{N}, 0.16-$ $0.30 \%$ of $\mathrm{P}$, and $0.58-1.12 \%$ of $\mathrm{K}[5,11,12]$. Thus, aside from being mulch, Pistia stratiotes have a potential source of NPK nutrients to substitute the need for inorganic fertilizer for the growth of Inpara 2.

Using of the DSS fertilization system at the study site $(50 \mathrm{~kg}$ urea/ha $+37 \mathrm{~kg} \mathrm{SP} 36 / \mathrm{ha}+24 \mathrm{~kg} \mathrm{KCl} / \mathrm{ha})$ which refers to the balance of crops nutrients needed based on the ability of the soil to supply nutrients provide results that are equivalent to those provided by fertilization recommendations in freshwater swampland (200 kg urea/ha $+150 \mathrm{~kg} \mathrm{SP} 36 / \mathrm{ha}+100 \mathrm{~kg} \mathrm{KCl} / \mathrm{ha}$ ). Balanced nutrient management will increase rice yield [13]. The response of plants to one nutrient is very dependent on the availability status of other nutrients. Several studies have shown that sufficient potassium nutrients will significantly increase the absorption and utilization of $\mathrm{N}$ and $\mathrm{P}$ by plants [14] as well as increase the response rate of $\mathrm{N}$ and $\mathrm{P}$ fertilizer utilization [15]. The application of $\mathrm{K}$ fertilizer also increases carbohydrate and $\mathrm{N}$ metabolism and therefore increases the quality of plant products [16].

The results obtained on the application of the DSS fertilization system combined both with and no Pistia stratiotes indicated an efficiency of fertilizer using $400 \%$ compared to the recommended fertilization for freshwater swampland. Thus, the use of inorganic fertilizers can be reduced so that production costs can be saved

\section{Conclusion}

Technological improvement in the management of medium freshwater swampland through water management with a mini polder system, the use of high yield variety such as Inpara 2, Jarwo 2:1 planting system, $15 \mathrm{t} / \mathrm{ha}$ of Pistia stratiotes, $25 \mathrm{~kg}$ of bio-fertilizer Biotara/ha, DSS fertilization system (50 kg urea/ha +37 $\mathrm{kg} \mathrm{SP36/ha}+24 \mathrm{~kg} \mathrm{KCl} \mathrm{ha),} \mathrm{and} \mathrm{the} \mathrm{management} \mathrm{of}$ integrated plant pest organisms yielded $7.62 \mathrm{t} / \mathrm{ha}$. This treatment increased yield by $10.28 \%$ compared to controls (6.91 t/ha) and 52.40-69.33\% higher than the results obtained by local farmers $(4.5-5.0 \mathrm{t} / \mathrm{ha})$. Thus, it can save production costs, because of reducing the use of inorganic fertilizers.

\section{References}

1. M. Noor, Rawa lebak: ekologi, pemanfaatan dan pengembangannya, PT. RajaGrafindo, Jakarta, 274 hal, (2007)

2. K. Nugroho, Alkasuma, Paidi, W. Wahdini, Abdurachman, H. Suhardjo, IPG. Widjaja Adhi, Peta areal potensial untuk pengembangan pertanian lahan rawa pasang surut, rawa dan pantai, Proyek Penelitian Sumberdaya Lahan, Pusat Penelitian Tanah dan Agroklimat, Bogor, (1992)

3. BBSDLP (Balai Besar Penelitian dan Pengembangan Sumberdaya Lahan Pertanian), Laporan teknis no. 1/dok./bbsdlp/2014. luas, penyebaran dan potensi sumberdaya lahan pertanian nasional, (2014)

4. Noorginayuwati, S. Nurzakiah, Pengembangan inovasi teknologi pengelolaan lahan rawa berkelanjutan, Laporan akhir RPTP/RDHP tahun 2015, Balittra, Banjarbaru, (2015)

5. D. Nazemi, I. Ar-Riza, Jenis rumput air di lahan lebak dan potensinya sebagai pupuk organik bagi tanaman padi rawa, Prosiding seminar himpunan ilmu gulma indonesia (HIGI), Medan, (1998)

6. G.X. Xing, Z.L. Zhu, An assessment of $\mathrm{N}$ loss from agricultural fields to the environment in China, Nutr. Cycl.Agroecosyst, 57: 67-73, (2000)

7. M. Alwi, A. Fahmi. Decision Support System (DSS) pemupukan padi lahan rawa, Prosiding seminar nasional inovasi teknologi pertanian Banjarbaru, 20 Juli 2016, Balai Penelitian Pertanian Lahan Rawa, Hal. 366-374, (2016)

8. Balai Penelitian Tanah, Petunjuk teknis analisis kimia tanah, tanaman, air, dan pupuk, Badan Penelitian dan Pengembangan Pertanian Departemen Pertanian, 136p, (2005)

9. Suparwoto, Waluyo, Peningkatan produksi padi di rawa lebak melalui perbaikan varietas dan sistem tanam jajar legowo, Prosiding seminar nasional lahan suboptimal "intensifikasi pengelolaan lahan suboptimal dalam rangka mendukung kemandirian pangan nasional", S. Herlinda, B. Lakitan, Sobir, Koesnandar, Suwandi, Puspitahati, M.I. Syafutri, D. 
Meidalima (Eds.), Palembang, 20-21 September 2013, ISBN 979-587-501-9, (2013)

10. http://bbpadi.litbang.pertanian.go.id/index.php/variet as-padi/inbrida-padi-rawa-inpara/inpara-2, (2019)

11. A. Hairani, K. Anwar, M. Saleh, M.A. Susanti, Penelitian perbaikan teknologi peningkatan produktivitas lahan lebak untuk meningkatkan produksi padi dan cabai, Laporan akhir RPTP/RDHP tahun 2017, Balittra, Banjarbaru, (2017)

12. A. Hairani, Y. Rina, M. Saleh, A. Susilawati, M.A. Susanti. Penelitian perbaikan teknologi budidaya terpadu padi dan cabai pada lahan lebak tengahan, Laporan hasil penelitian balai penelitian pertanian lahan rawa, Banjarbaru, 75 hal, (2018)

13. A. Dobermann, T. Fairhurst, Rice: nutrient disorders and nutrient management, IRRI, Makati city, The Phillipines, 191p, (2000)

14. A. Barnes, D.J. Greenwood, T.J. Cleaver, A dynamic model for the effect of potassium and nitrogen fertilizers on the growth and nutrient uptake of crops, J.Agric.Sci, 86, 225-244, (1976)

15. J.B. Reid, S.N. Trolove, Y. Tan, P.R. Johnstone, Nitrogen or potassium preconditioning affects uptake of both nitrate and potassium in young wheat (Triticum aestivum), Ann. Appl. Biol. 168, 66-80, (2016)

16. R. Gaj, D. Gorski, J. Przybyl, Effect of differentiated phosphorus and potassium fertilization on winter wheat yield and quality, J. Elem. 18, 55-67, (2013) 